\title{
ANALISIS DAN KLASIFIKASI SEDIMEN PERMUKAAN DASAR LAUT MENGGUNAKAN SUB-BOTTOM PROFILER
}

\author{
ANALYSIS AND CLASSIFICATION OF THE NEAR-SURFACE SEDIMENT \\ USING SUB-BOT'TOM PROFILER
}

\author{
Saifur Rohman ${ }^{1}$, Henry M. Manik ${ }^{2}$, Totok Hestirianoto ${ }^{2}$, dan Imam Mudita ${ }^{2}$ \\ ${ }^{1}$ Program Studi Teknologi Kelautan, Sekolah Pascasarjana \\ ${ }^{2}$ Departemen Ilmu dan Teknologi Kelautan \\ Fakulltas Perikanan dan Ilmu Kelautan, Institut Pertanian Bogor \\ Korespondensi: srohm4n@gmail.com
}

\begin{abstract}
The increased human activity in the marine sector, such as dredging operations, oil and gas exploration, mineral sands mining and various marine research has led to an imperative demand for accurate seafloor maps. Sub-bottom profilers (SBP) are acoustic systems traditionally used to image sediment layers and rocks beneath the seabed, providing information about sediment thicknesses and stratigraphy. Therefore, the objectives of this research were to determine the profile of the seafloor sediment layer (near-surface sediment) and obtain the value of the reflection coefficient of the layer. The process of data acquisition was conducted using SBP type of a single channel sparker by BPPT that was the survey of oil and gas pipeline maintenance and electrical cable Pertamina in 2010, which was on the east coast Balongan, Indramayu. Whereas for seafloor sediment sampling was used gravity corer. The results of the processing of the raw data with Matlab nearby B19 have been obtained 2D profile of seabed sediments and reflector, which was clearly visible and had a reflection coefficient value range 0 to 0.2955 . In addition, an analytical technique for parameter estimation of sediment from laboratory data was performed as a comparison. The result of sediment in the form of silt with reflection coefficient value was 0.2807 .
\end{abstract}

Keywords: reflection coefficient, signal processing, sub-bottom profiler, two dimensional

\begin{abstract}
ABSTRAK
Peningkatan aktivitas manusia di bidang kelautan seperti operasi pengerukan (dredging), eksplorasi minyak dan gas, penambangan pasir mineral, dan berbagai penelitian kelautan telah mengakibatkan permintaan yang mendesak terhadap peta dasar laut yang akurat. Sub-bottom Profiler (SBP) adalah sistem akustik tradisional yang digunakan untuk menggambarkan lapisan sedimen dan batuan di bawah dasar laut, serta memberikan informasi tentang ketebalan sedimen dan stratigrafinya. Oleh karena itu, tujuan dari penelitian ini yaitu menentukan profil lapisan sedimen dasar laut (near-surface sediment) dan memperoleh nilai koefisien refleksi dari lapisan tersebut. Proses akuisisi data dilakukan menggunakan SBP jenis sparker single channel oleh BPPT, yaitu survei pemeliharaan pipa migas dan kabel listrik Pertamina tahun 2010 yang berada di sebelah timur pantai Balongan, Indramayu. Pengambilan sampel sedimen dasar laut menggunakan gravity corer. Hasil dari pengolahan data mentah SBP dengan Matlab di dekat lokasi B19 diperoleh profil 2D dari lapisan sedimen dimana terlihat jelas dasar laut dan reflektornya serta memiliki nilai koefisien refleksi berkisar 0-0.2955. Selain itu teknik analitis untuk estimasi parameter sedimen dari data laboratorium ditunjukkan sebagai pembanding. Hasil sedimennya berupa silt/lanau dengan nilai koefisien refleksinya adalah 0.2807.
\end{abstract}

Kata kunci: dua dimensi, koefisien refleksi, pemrosesan sinyal, sub-bottom profiler 


\section{PENDAHULUAN}

Aktivitas kelautan yang terus meningkat baik di bidang penambangan seperti pasir dan mineral, operasi pengerukan (dredging), eksplorasi minyak dan gas, maupun berbagai penelitian kelautan telah menyebabkan peningkatan permintaan peta-peta utama dasar laut, sebagai bahan acuan atau gambaran akan kondisi dasar laut untuk mengoptimalkan kinerja mereka. Sub-bottom Profiler (SBP) adalah sistem akustik tradisional yang digunakan untuk menggambarkan lapisan sedimen dan batuan di bawah dasar laut, serta memberikan informasi tentang ketebalan sedimen dan stratigrafinya (English Heritage 2013).

Beberapa tahun terakhir, metode akustik juga telah digunakan untuk mengukur proses dan struktur sedimen skala kecil, dengan resolusi temporal dan spasial tinggi, dan telah banyak diadopsi oleh para peneliti kelautan karena kemampuannya dalam mengumpulkan data secara cepat dan tidak merusak (Davis et al. 2002; Kim et al. 2002). Sehingga medote ini sangat membantu dalam menganalisis dan memberikan informasi tentang lapisan sedimen dasar laut dengan biaya yang terjangkau.

Berdasarkan hal tersebut, maka penelitian ini menggunakan data dari Balai Pengkajian dan Penerapan Teknologi (BPPT), yaitu survei pemeliharaan pipa migas dan kabel listrik Pertamina tahun 2010 yang berada di sebelah timur pantai Balongan, Indramayu. Dimana proses akuisisi data menggunakan SBP jenis Sparker (single channel) dengan bantuan software SonarWiz dan pengambilan data sedimen dasarnya menggunakan sistem coring. Selanjutnya dilakukan analisis laboratorium dari sedimen yang didapat. Pemrosesan sinyal digital dari raw data SBP dilakukan dengan menggunakan Matlab.

Oleh karena itu, tujuan dari penelitian ini adalah memperoleh gambaran profil dua dimensi (2D) lapisan sedimen permukaan dasar laut (near-surface sediment) dan menentukan nilai koefisien refleksinya berdasarkan pemodelan dan perhitungan secara analitis.

\section{METODE PENELITIAN}

Survei geologi dan geofisika Pertamina dilakukan oleh BPPT pada tanggal 6-27 November 2010 di sebelah timur pantai
Balongan, Indramayu (Gambar 1). Data di lokasi B19 yang digunakan pada penelitian ini diambil pada tanggal 20 November 2010 . Pemilihan lokasi B19 didasarkan pada topografi dasar lautnya yang horizontal dan kualitas data pemerumannya yang baik. Sehingga diharapkan dapat lebih stabil ketika diaplikasikan pemodelan.

Peralatan akuisisi data yang digunakan dalam survei SBP ini yaitu 1 unit applied acoustic squid 500 sparker, 1 unit seismic energy source, 1 set Hydrophone single channel, dan 1 set komputer yang terinstal software SonarWiz Map 4. Adapun untuk pengambilan data sedimen dasar laut yaitu dengan gravity corer. Dimana menggunakan sistem gravitasi yang terdiri dari 3 bagian yaitu pemberat, pipa, dan catcher (penahan).

Konversi data SBP dilakukan untuk mempermudah pengolahan raw data di Matlab yaitu sebagai berikut (Gambar 2).

\section{Informasi waktu dan frekuensi dari raw data}

Informasi time-frequency dalam penelitianinidiperoleh dengan menggunakan Short Time Fourier Transform (STFT). STFT adalah sebuah teknik yang dikembangkan oleh Denis Gabor, digunakan untuk analisis bagian kecil dari sebuah sinyal berdasarkan pada transformasi Fourier dan Windowing. Hasil dari STFT ini adalah sinyal dipetakan menjadi sebuah fungsi 2 dimensi dalam waktu dan frekuensi. Rumus Nyquist frequency $\left(f_{N}\right)$ yang digunakan yaitu sebagai berikut:

$$
\mathrm{f}_{\mathrm{N}}=\frac{1}{2 \Delta t}
$$

Dimana :

$\left(f_{S}\right)=$ adalah frekuensi sampling $\left(f_{\mathrm{S}}=1 / \Delta \mathrm{t}, \mathrm{Hz}\right)$,

$\Delta t=$ interval sampling (s)

Nyquist interval $=$ rentang frekuensi

(the frequency range) dari

$0-\mathrm{f}_{\mathrm{N}}$ (Kearey et al. 2002)

\section{Pengolahan data matlab}

Setelah data dikonversi dan diekstrak nilai amplitudonya. Maka selanjutnya data diolah dalam matlab yang ditunjukkan pada (Gambar 3).

\section{Dekonvolusi sparse spike}

Metoda Norma L1 adalah metoda 
inversi rekursif dengan menggunakan asumsi sparse spike. Teori dasar metode ini dikemukakan oleh Oldenburg, pada bagian awalnya didiskusikan model konvolusional bebas noise (Abdullah 2008).

Prinsip dari metode ini hampir sama dengan dekonvolusi spike (Mousa \& Al-Shuhail 2011) yaitu trace $(\mathrm{s}(\mathrm{t}))$ dikonvolusikan dengan wavelet sumber $(\mathrm{w}(\mathrm{t}))$ yang merupakan hasil model/filter dalam bentuk zero-phase, sehingga diperoleh reflektivitas $r(t)$ sebagai berikut:

$$
\begin{gathered}
\mathbf{s}(\mathrm{t})=w(t)^{*} r(t) \\
\mathrm{r}=\left(w^{*} w\right)^{-1} w^{*} s \\
\mathrm{r}(\mathrm{t})=w(t)^{*} s(t)
\end{gathered}
$$

Selanjutnya menggunakan aljabar linier norma L1 untuk meminimalisir penjumlahan dari kekuatan refleksi absolut, yaitu sebagai berikut:

$$
\mathrm{f}(\mathrm{r})=|| w r-s||^{2}+a|r|
$$

Dimana || || adalah nilai panjang vektor/ norm dan a adalah regularization parameter, yaitu 0.1 (Sacchi 2008; Wang 2011).

Wavelet sumber diekstraksi dengan membuat wavelet ricker (zero-phase), frekuensi yang digunakan adalah $120 \mathrm{~Hz}$ dengan sampling interval $0.001 \mathrm{~s}$ (Gambar 4). Parameter inversi model sparse spike yang digunakan adalah :

1. Regularization parameter 0.1

2. Maximum number of iterations 15

3. Processing sample rate $1 \mathrm{~ms}$

4. Data yang digunakan adalah raw data setelah koreksi amplitudo.

\section{Perhitungan analisis data sedimen}

Data coring dari lokasi survei dilakukan analisis laboratorium untuk menentukan nilai densitas dan jenis sedimennya. Selanjutnya, Untuk menentukan kecepatan gelombang seismik dalam sedimen digunakan deskriptor sedimen mean grain size $\left(\mathrm{M}_{\mathrm{Z}}\right)$, yang diukur dalam unit logaritmik (APL 1997) yaitu sebagai berikut:

$$
\mathrm{M}_{\mathrm{Z}}=-3.32 \log _{10} \frac{d}{d_{0}}
$$

Dimana $d=$ diameter butiran sedimen $(\mathrm{mm})$, $d_{0}=$ panjang referensi $(1 \mathrm{~mm})$, dan $\Phi=$ notasi unit dari $\mathrm{M}_{\mathrm{z}}$. Nilai dari $\mathrm{M}_{\mathrm{z}}$ yang diperoleh, kemudian disubstitusikan ke dalam persamaan regresi untuk mengestimasi kecepatan sedimen, hasil formula Bachman dan Hamilton. Bentuk persamaan regresinya adalah sebagai berikut (Saleh 2010):

$$
\mathrm{C}_{\mathrm{S}}=1952-86.3 M_{Z}+4.14 M_{Z}^{2}
$$

Koefisien refleksi dihitung dengan menggunakan persamaan Zoeppritz dengan prinsip dasar hukum Snellius dalam penentuan koefisien reflektivitas dari impedansi akustik (acoustic impedance, Z). Dimana impedansi akustik merupakan produk dari perkalian densitas basah $(\rho)$ dengan kecepatan penjalaran gelombang kompresi atau seismik (c) atau $Z=\rho . c$ (Caulfield et al. 2005). Secara sederhana persamaan Zoeppritz yaitu sebagai berikut:

$$
\begin{gathered}
A 1+A 2=A O \text { dan } \\
Z 1 A 1-Z 2 A 2=-Z 1 A O, \\
R=\frac{A_{1}}{A_{0}}=(Z 2-Z 1) /(Z 2+Z 1) \\
T=\frac{A_{2}}{A_{0}}=2 Z 1 /(Z 1+Z 2)
\end{gathered}
$$

Dimana:

$A O=$ amplitudo datang/incident

$A 1$ = amplitudo yang dipantulkan

A2 = amplitudo yang ditransmisikan

$Z 1$ = impedansi pada lapisan pertama

$Z 2$ = impedansi pada lapisan kedua

$R$ adalah koefisien refleksi amplitudo

$T$ adalah koefisien transmisi amplitudo.

Nilai $R$ memiliki kisaran $-1 \leq R \leq 1$ dan nilai negatif dari $R$ menunjukkan adanya perubahan fase dari $\pi$ (1800) dari gelombang kompresi yang dipantulkan (Kearey et al. 2002). Hal ini terjadi jika impedansi pada lapisan pertama lebih besar daripada lapisan kedua. 


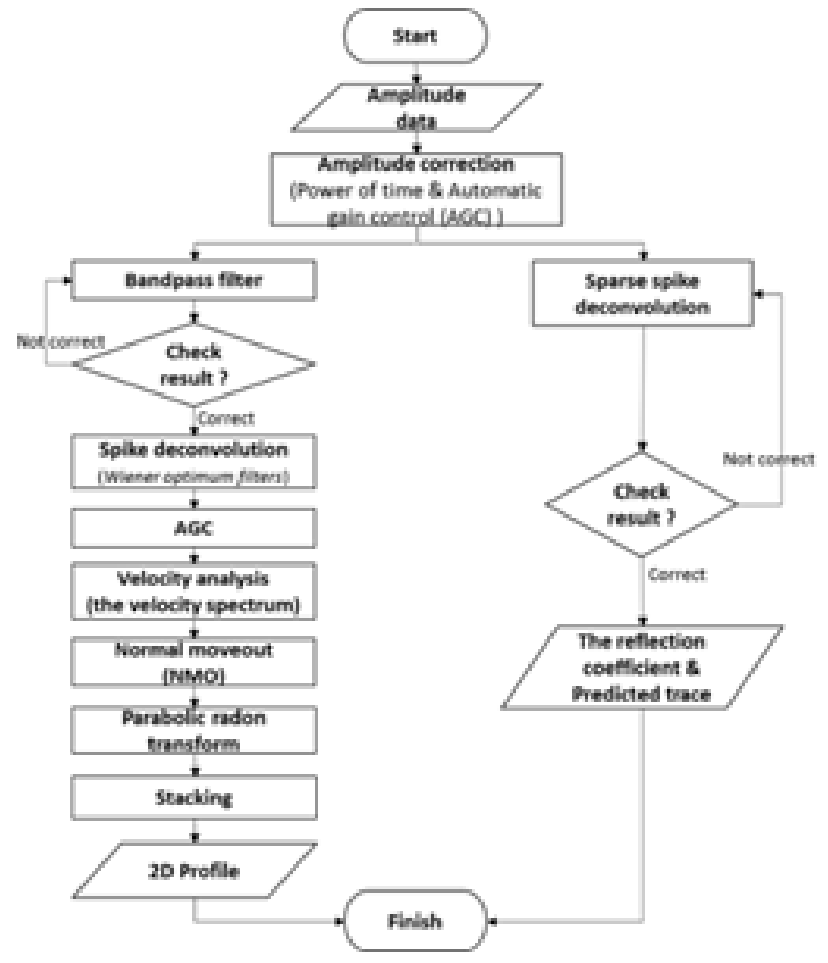

Gambar 3 Diagram alir pengolahan data di matlab

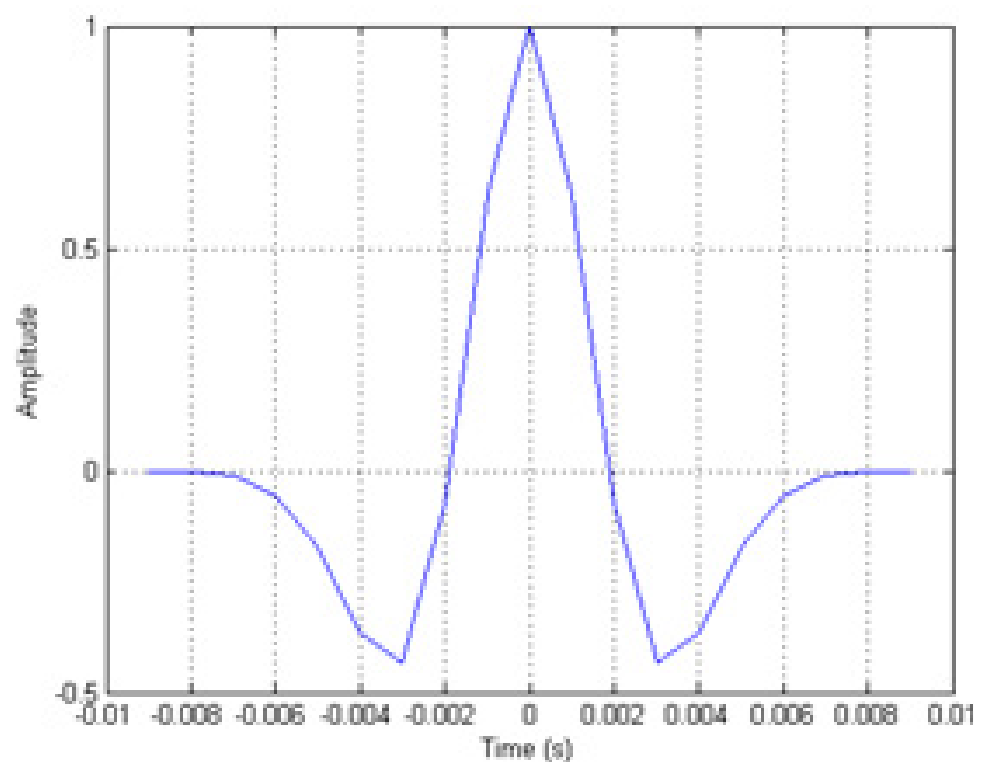

Gambar 4. Wavelet ricker yang diaplikasikan

\section{HASIL DAN PEMBAHASAN}

\section{Informasi waktu dan frekuensi dari data}

Hasil konversi data diperoleh bahwa jarak perekaman per ping suara atau jarak antar trace berkisar 0.7626 meter dan interval sampling adalah $0.10 \mathrm{~ms}$. Fungsi spectrogram di Matlab digunakan untuk menjalankan STFT. Sehingga dapat dihasilkan Gambar 5. Dimana rentang frekuensi yang diperoleh dari data berkisar antara $0-5 \mathrm{kHz}$.

\section{Profil 2D di lokasi dekat B19}

Hasil dari pengolahan di matlab diperoleh profil 2 dimensi secara vertikal (Gambar 6), dimana sumbu x menunjukkan offset atau jarak keseluruhan trace sekitar 
$45.76 \mathrm{~m}$ dan sumbu y menunjukkan kedalaman dalam meter. Kedalaman substrat dasar terlihat berada di kedalaman sekitar $13 \mathrm{~m}$. Reflektor pertama atau lapisan sedimen yang kontras densitasnya jelas terlihat pada kedalaman sekitar 27 m. Hal ini berarti ketebalan sedimen di lapisan permukaan yang relatif homogen memiliki ketebalan $14 \mathrm{~m}$. Selanjutnya, tidak ditemukan reflektor yang kedua hingga kedalaman lebih dari $75 \mathrm{~m}$.

Hasil dari sistem coring di lokasi B19 adalah jenis sedimen permukaan berupa silt/lanau. Contoh sedimen yang dianalisis di laboratorium yaitu setebal 0.95 $\mathrm{m}$. Posisi sedimen di lokasi B19 adalah E 108028'14.48" dan S 06019'58.03". Profil 2 dimensi dalam 3 bentuk yang berbeda yaitu seperti pada (Gambar 6).

\section{Koefisien Refleksi Hasil Pemodelan}

Hasil dari dekonvolusi sparse spike berupa estimasi full-bandwith reflektivitas (Gambar 7). Oleh karena itu, kita dapat mengetahui pendekatan dari nilai koefisien refleksi yang ada di lokasi B19. Nilai koefisien refleksi dari pemodelan tersebut (lokasi B19) berkisar antara -0.23-0.19.

Nilai koefisien refleksi negatif berarti bahwa impedansi atau produk dari perkalian densitas basah $(\rho)$ dengan kecepatan suara (c) di lapisan atas lebih besar dibanding lapisan di bawahnya. Sehingga dapat dikatakan nilainya berkisar $0-0.23$. Nilai 0 berarti energi ditransmisikan atau diteruskan seluruhnya dikarenakan impedansinya yang relatif homogen.

Nilai koefisien refleksi tersebut digunakan untuk mengetahui kontras impedansi antar lapisan sedimen. Dimana refleksi menunjukkan perbandingan nilai energi yang dipantulkan dibanding energi yang dating.

Caulfield et al. (2005) menghasilkan nilai koefisien refleksi near-surface sediment berkisar 0.04-0.30. Sehingga dapat dikatakan bahwa nilai koefisien refleksi sedimen berbeda-beda. Hal ini dipengaruhi oleh nilai kecepatan suara, frekuensi yang digunakan, dan densitas dari lapisan sedimen bawah permukaan laut yang memiliki sifat fisis beragam.

Hasil dari pemodelan dapat dilakukan analisis seberapa dekat hubungan antara trace asli hasil perekaman alat dengan trace hasil pemodelan (predicted trace). Gambar 8 menunjukkan bahwa antara trace asli dengan trace hasil prediksi keduanya memiliki cukup kesamaan. Analisis lebih lanjut hubungan antara kedua trace tersebut dilakukan pencarian korelasi antar kedua trace tersebut, yaitu dengan menggunakan cross correlation.

Hasil korelasi (Gambar 9) dapat diketahui bahwa nilai koefisien korelasi dari keduanya yang cukup baik yaitu didominasi nilai lebih besar dari 0.6 dengan selang koefisien korelasi secara keseluruhan data yaitu antara 0.4-1. Hal ini berarti hubungan antara trace asli hasil perekaman memiliki derajat keeratan/kesamaan yang cukup kuat dengan trace hasil prediksi/pemodelan. Hasil dari ketiga data tersebut yaitu sebagai berikut (Gambar 8 dan 9).

\section{Perhitungan analitis sedimen}

Hasil analisis sedimen dari laboratorium (Tabel 1). Hasil dari perhitungan manual koefisien refleksi di lokasi B19 diperoleh bahwa dengan menggunakan persamaan Zoeppritz (Tabel 2), nilai koefisien refleksi (R) dari sedimen silt/lanau yang ada di permukaan berkisar 0.28 dan koefisien transmisi (T) 0.71. Dimana hasil dari formula diperoleh nilai kecepatan sedimen (c) sebesar 1947.4701 $\mathrm{m} / \mathrm{s}$ dan densitas ( $\rho)$ dari analisis laboratorium sebesar $1445 \mathrm{~kg} / \mathrm{m}^{3}$. Sehingga dapat dikatakan bahwa hasil perhitungan koefisien refleksi dengan pemodelan dan manual menunjukkan nilai yang hampir sama tetapi lebih detil hasil dari pemodelan.

Hamilton menyebutkan bahwa nilai koefisien refleksi rata-rata dari sedimen jenis lanau berlempung (Clayey silt) adalah 0.17 dan lanau berpasir (Sandy silt) adalah 0.21 (LeBlanc et al. 1992). Li (2012) mencatat bahwa nilai koefisien refleksi dari sedimen dasar laut berupa lanau (Silt) adalah 0.160.17 dan lanau berpasir (Sandy silt) adalah 0.21-0.37. 

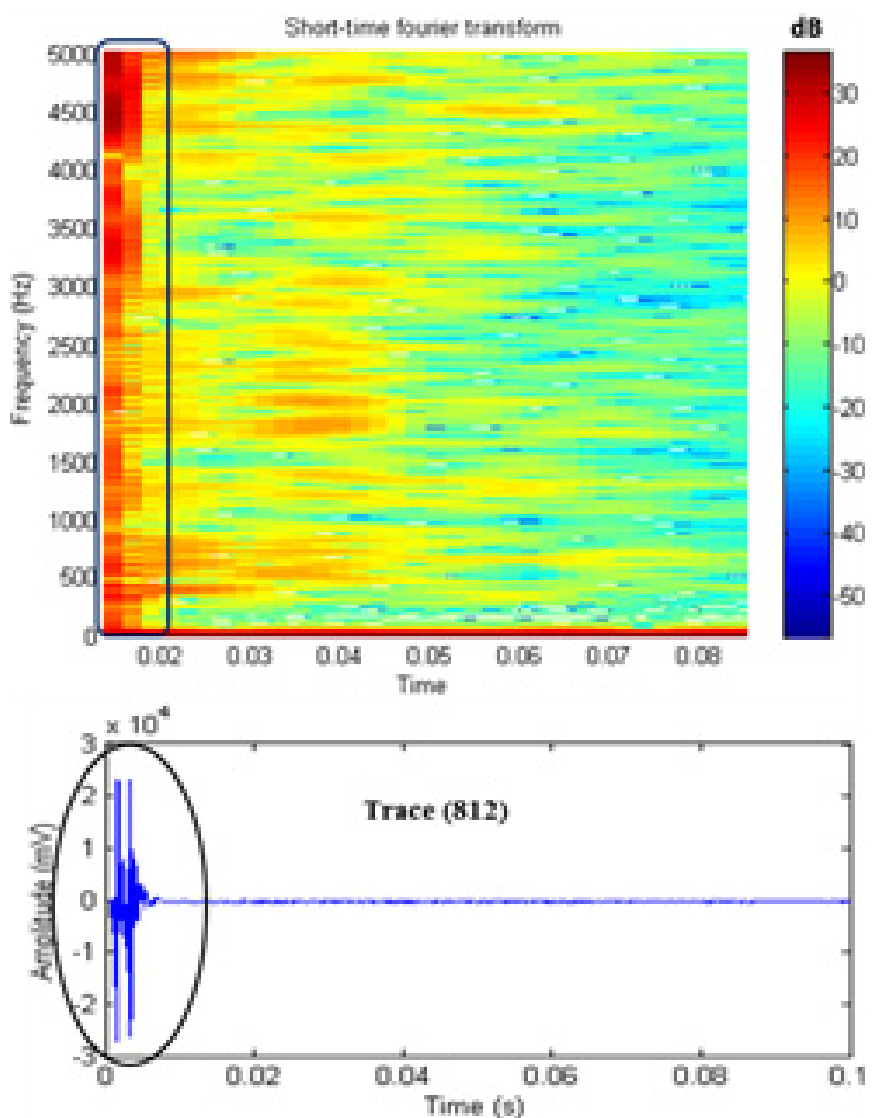

Gambar 5. . Hasil spectrogram dari trace ke-812 di lokasi B19

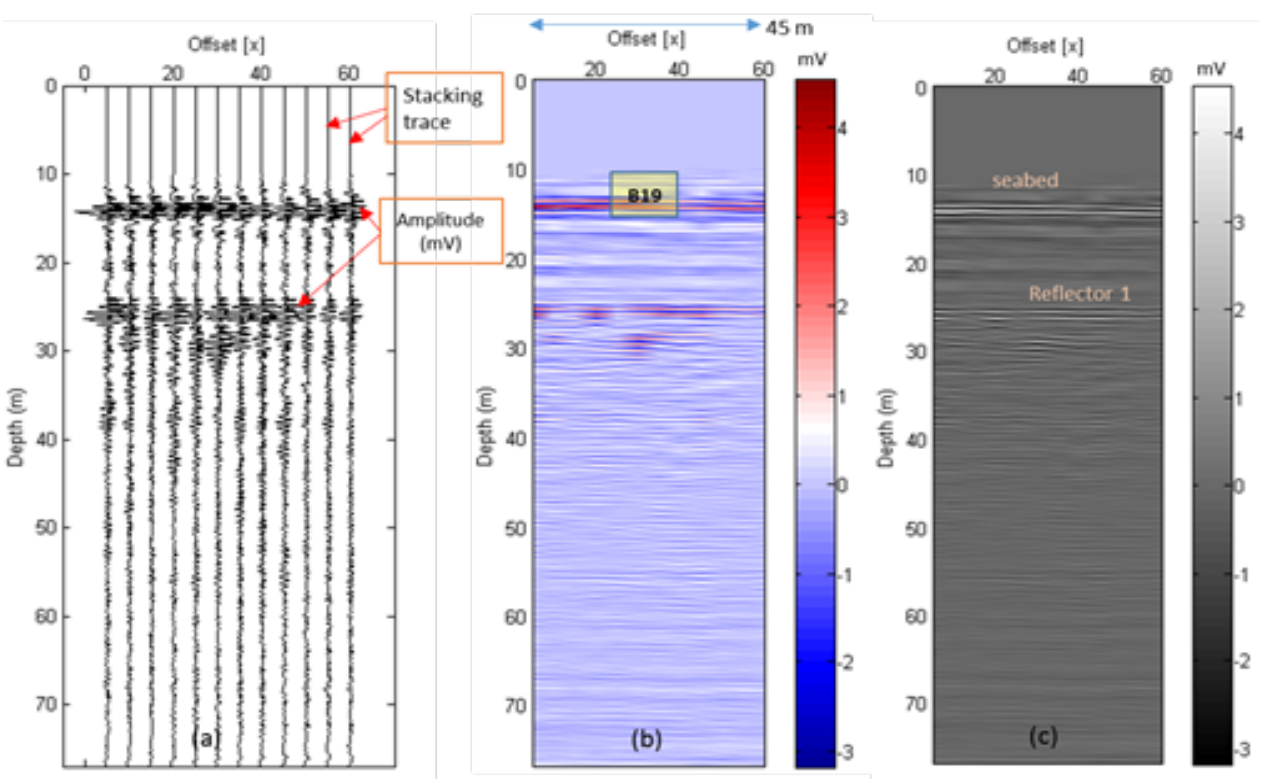

Gambar 6. Hasil dari penggabungan trace di lokasi B19: (a) dalam bentuk wiggles, (b) dalam color scale, dan (c) gray scale dalam amplitudo (mV) 


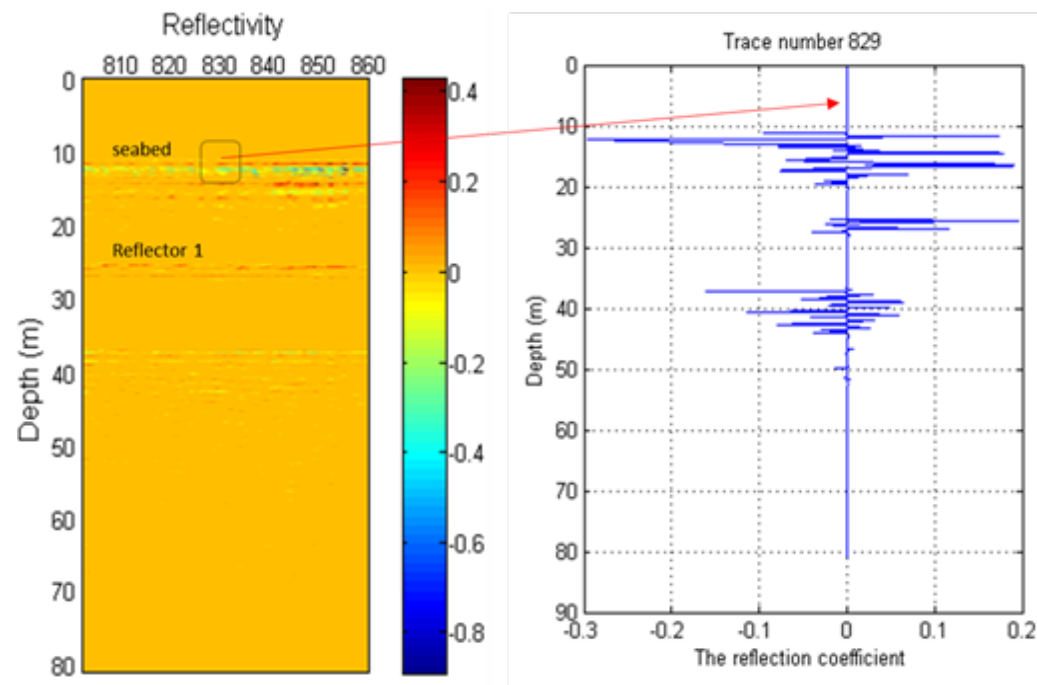

Gambar 7. Hasil klasifikasi: kiri adalah nilai koefisien refleksi sedimen dari seluruh trace dan kanan adalah koefisien refleksi dari single trace

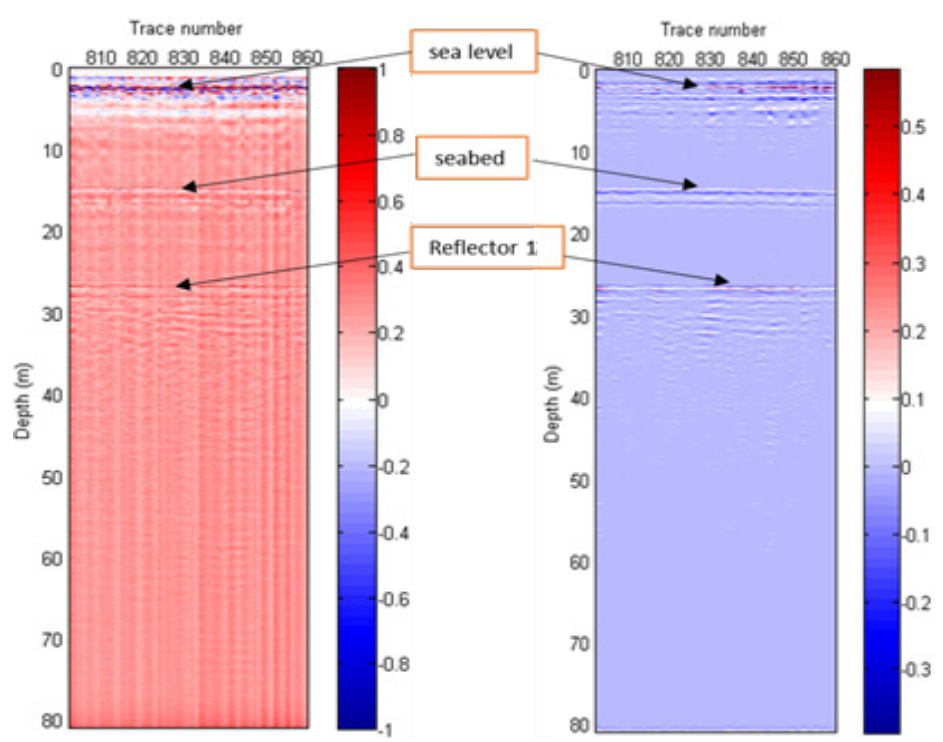

Gambar 8. Kiri adalah trace seismik hasil rekaman dan kanan adalah trace hasil prediksi/sintetik (Hasil konvolusi koefisien refleksi/r(t) dengan wavelet sumber/w(t))

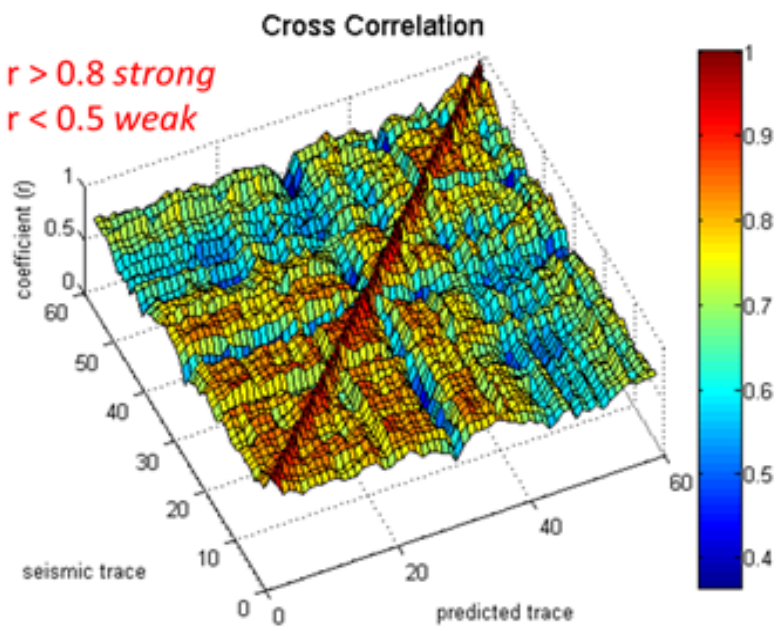

Gambar 9. Koefisien korelasi antara trace sintetik dengan trace seismik hasil rekaman 
Tabel 1. Hasil analisis dari data coring B19

\begin{tabular}{ccccl}
\hline & Indeks Properties & Simbol & Unit & \multicolumn{1}{c}{ Value } \\
\hline 1 & Density & $\rho$ & $\mathrm{gr} / \mathrm{cm}^{3}$ & 1.44 \\
2 & Water content & $\mathrm{w}$ & $\%$ & 84.87 \\
3 & Specific of gravity & $\mathrm{Gs}$ & - & 2.33 \\
& Void ratio & $\mathrm{e}$ & - & 1.98 \\
& Porosity & $\mathrm{n}$ & - & 0.66 \\
4 & Degree of saturation & $\mathrm{Sr}$ & $\%$ & 99.77 \\
& Plastic limit & $\mathrm{PL}$ & $\%$ & 33.60 \\
& Liquit limit & $\mathrm{LL}$ & $\%$ & 86.75 \\
& Plasticity index & $\mathrm{PI}$ & $\%$ & 53.15 \\
& Grainsize Gravel & $\mathrm{G}$ & $\%$ & 0 \\
& Sand & $\mathrm{S}$ & $\%$ & 0.78 \\
& Silt & $\mathrm{M}$ & $\%$ & 98.72 \\
& Clay & $\mathrm{C}$ & $\%$ & 0.50 \\
\hline
\end{tabular}

Tabel 2. Hasil analisis dari data coring B19

Lokasi B19 (Jenis Sedimen Silt/Lanau)

\begin{tabular}{lccccc}
\hline $\mathrm{d}_{\text {mean }}(\mathrm{mm}) *$ & $\mathrm{Mz} *$ & $\begin{array}{c}\mathrm{C}(\mathrm{m} / \mathrm{s}) / \text { hasil } \\
\text { formula }\end{array}$ & $\rho\left(\mathrm{kg} / \mathrm{m}^{3)}\right.$ & $\begin{array}{c}\text { Koef. Refleksi } \\
(\mathrm{R})\end{array}$ & $\begin{array}{c}\text { Koef. Transimis } \\
(\mathrm{T})\end{array}$ \\
\hline 1.038226 & 0.05262 & 1947.4701 & 1.445 & 0.2807 & 0.7193 \\
\hline $\mathrm{d}_{\text {mean }}=$ diameter rata-rata butiran sedimen: $\mathrm{Mz}=$ meanara.in size &
\end{tabular}

\section{KESIMPULAN}

Hasil pemrosesan sinyal di Matlab diperoleh peta berupa profil 2D sedimen dasar laut dari data Sub-bottom Profiler. Sedimen permukaan dasar memiliki ketebalan sekitar 14 meter terhadap batas reflektor pertama. Nilai koefisien refleksi sedimen di lokasi B19 hasil pemodelan berkisar 0 hingga 0.23 . Hasil secara manual menunjukkan nilai koefisien refleksi yaitu jenis sedimen permukaan silt/lanau bekisar 0.2807. Sebagai sumber informasi yang lebih lengkap hasil pemodelan lebih aplikatif dibanding perhitungan secara analitis.

\section{DAFTAR PUSTAKA}

[APL] Applied Physics Laboratory. 1997. Apl- Uw High Frequency Ocean Environmental Acoustic Models. Washington: Seattle.

Caulfield DD, Ballard RF, Leist RL. 2005. Analytical Techniques for shallow marine near-surface geotechnical parameter estimation. http:// books. google.co.id [diakses pada tanggal 12 Desember 2014 ].

Davis A, Haynes R, Bennell J, Huws D. 2002. Surficial seabed sediment properties derived from seismic profiler responses. Marine Geology. 182:209-223.

English Heritage. 2013. Marine geophysics data acquisition, processing and interpretation. http://eprints. ulster. ac.uk / 26229/1/ MGDAPAI-guidancenotes.pdf [diakses pada tanggal 24 Juni 2014].

Kearey P, Brooks M, Hill I. 2002. An Introduction to Geophysical Exploration. $3^{\text {rd }}$ edition. Oxford: Blackwell Science Ltd.

Kim HJ, Chang JK, Jou HT, Park GT, Suk BC, Kim KY. 2002. Seabed classification from acoustic profiling data using the similarity index. J. Acoust. Soc.Am. 111:794-799.

LeBlanc LR, Mayer L, Rufino M, Schock SG. 1992. Marine sediment classification using the chirp sonar. J. Acoust. Soc. Am. Vol 91

Li Q. 2012. Digital Sonar Design In Underwater Acoustics: Principles and Applications. https: // books. google.co.id [diakses pada tanggal 15 April 2015 ].

Mousa WA, Al-Shuhail AA. 2011. Processing of seismic reflection data using MATLAB. www. docin.com [diakses 
pada tanggal 20 Oktober 2014].

[MATLAB]. 2014. R2014b documentation: fast fourier transform. http://www. mathworks.com [diakses pada tanggal 22 Oktober 2014].

Sacchi, M.D. 2008. Signal analysis and imaging group. http://www.geo. phys.ualberta.ca/saig/Seismic Lab. [diakses pada tanggal 3 November 2014].
Saleh M. 2010. Seabed classification using sub-bottom profiler [Tesis]. Netherlands: Delft University of Technology.

Wang Y. 2011. Seismic impedance invertion using 11-norm regularization and gradient descent methods. $J$ Inv I Problems. (18):823-828. 